\title{
ACRL Microcard Series Abstracts of Titles
}

Four new titles, numbers 15 through i 8, are available in the ACRL MICROCARD SERIES. Abstracts of numbers I through 14 appeared in the July, I954 issue of C\&RL, and abstracts of subsequent titles in the series will be published in C\&RL as they appear.

All orders, whether standing orders or orders for single titles, are to be directed to the Micropublication Service, University of Rochester Press, Rochester 3, New York.

\section{FRAREY, CARLYLE JAMES}

Subject heading revision by the Library of Congress, I94I-I950. Rochester, N.Y., University of Rochester Press for the Association of College and Reference Libraries, 1954. (iii, 97 l. illus., tables. $29 \mathrm{~cm}$. ACRL MICROCARD SERIES, no. I5) Thesis (M.S. in L.S.) -Columbia University, 195 I. List of sources: 1. 94-97. 3 cards. $\$ .75$.

From an analysis of ten years' changes in a $4 \%$ sampling of the 4 th edition of the LC subject heading list this study attempts I) to assess the validity of criticisms of LC subject heading practice; 2) to determine whether trends in the development of the subject catalog are suggested by these revisions; and 3) to point out LC adherence to or departure from traditional patterns and practices in subject heading assignment.

The findings suggest that much criticism of LC practice is unjustified; new headings are established promptly, obsolete terminology is being modernized, see references are supplied generously, and discrimination is exercised in the use of see also references. A tendency towards increased specificity of headings and an increase in phrase and compound headings are noted in LC practice. The need for additional studies of traditional techniques and more economical methods of subject analysis are suggested by the scope of LC's subject heading revision program.

KAHN, ROSEANN

A history of the Peabody Institute Library, Baltimore, Maryland, I857-1916.
Rochester, N.Y., University of Rochester Press for the Association of College and Reference Libraries, I954. (viii, 87 l. illus., tables. $28 \mathrm{~cm}$. ACRL MICROCARD SERIES, no. 16) Thesis (M.S. in L.S.) -Catholic University of America, 1953. Bibliography: 1. 86-87. 3 cards. $\$ .75$.

When George Peabody provided $\$ 1,140,000$ for the establishment of the Peabody Institute, which was to consist of a library, lecture department, academy of music, and an art gallery, he stipulated that the library was not to be a popular library but an outstanding and extensive non-circulating reference library open to the public. Fifteen friends of Mr. Peabody were appointed by him to administer the library that was opened in 1866.

The first librarian, Dr. John G. Morris, a Lutheran minister and former board member, drew up a carefully planned list of books and sent an agent abroad for material. Dr. Morris was succeeded by Philip Uhler and John Parker. Under Uhler plans were made to construct a second building exclusively for the library and the work was begun on the first printed catalog of the holdings. Parker introduced the Dewey Decimal system and prepared the second printed catalog.

With the coming of the Enoch Pratt Free Public Library patronage of the Peabody decreased but only temporarily. The budget remained stable and the trustees never deviated from the initial purpose of the library.

\section{HINTON, MARGARET OWEN}

An evaluation of college and university 
library handbooks for students. Rochester, N.Y., University of Rochester Press for the Association of College and Reference Libraries, I954. (iii, 83 l. tables. $29 \mathrm{~cm}$. ACRL MICROCARd SERIES, no. I 7 ) Thesis (M.S. in L.S.) -Columbia University, 1950. Bibliography: 1. 82-83. 3 cards. $\$ .75$.

. The primary object of this study was to determine whether or not the content and physical make-up of existing library handbooks for students make it possible for the students to have the most intelligent and effective use of their institutional libraries. Data were assembled from a survey of 230 colleges and universities having liberal arts libraries. The findings were briefly as follows:

I. Library handbooks for students are of definite and accepted value, both as a teaching aid and as a primary means of guiding students in the fullest use of their libraries.

2. Library handbooks do not have adequate content and therefore do not completely fulfill their purpose.

3. Costs for construction and distribution varied.

4. The median number of pages was fifteen.

5. Only 80 surveyed schools used handbooks but the others expressed themselves in favor of them and their principal uses.
6. Less than half of the 150 libraries without handbooks or substitutes for them used some other method of teaching students the use of the library. The most common one was inclusion of library usage in Freshman English courses.

7. There exists a definite need for a board of qualified librarians to study the handbook problem, particularly in regard to adequate content.

\section{THOMPSON, LAWRENCE SIDNEY}

Foreign travellers in the South, I900I950. Rochester, N.Y., University of Rochester Press for the Association of College and Reference Libraries, I954. (ii, I 87 p. $26 \mathrm{~cm}$. ACRL MICROCARD SERIES, no. I8) 5 cards. \$I.25.

This bibliography includes full length books in foreign languages published between 1900 and 1950 which deal with some aspect of travel in each of the following states: Maryland, Virginia, North Carolina, South Carolina, Georgia, Florida, Alabama, Mississippi, Louisiana, Texas, Oklahoma, Arkansas, Tennessee, and Kentucky. Each book is accompanied by a brief critical annotation. There is an introductory essay which analyzes the picture of the South presented by over 400 writers whose books are indexed in the bibliography. An index includes authors, titles, and subjects.

\section{Corrections}

Prices for Robert L. Talmadge, "Practices and policies of the reference departments of large university libraries concerning the preparation of bibliographies" (ACRL MICROCARD SERIES no. 3 ) and Horace R. Archer, "A survey of the history of printing, type-founding and bookselling in seventeenth century England" (ACRL MICROCARD SERIES no. 7) were incorrectly noted in the July, I 954 issue of c\&RL. Talmadge should be two cards, \$.50, and Archer should be four cards, \$1.0o.

\section{Eastern College Librarians}

The 4oth Conference of Eastern College Librarians will take place on Saturday, November 27, 1954 in the McMillin Theater of Columbia University. The theme selected for this Conference is Library-Instructional Integration on the College Level. 